\title{
An assessment of drinking-water quality post-Haiyan
}

\author{
Bonifacio Magtibay, ${ }^{a}$ Maria Sonabel Anarnab and Arturo Fernando ${ }^{a}$ \\ Correspondence to Bonifacio Magtibay (email: magtibaybo@wpro.who.int).
}

Introduction: Access to safe drinking-water is one of the most important public health concerns in an emergency setting. This descriptive study reports on an assessment of water quality in drinking-water supply systems in areas affected by Typhoon Haiyan immediately following and 10 months after the typhoon.

Methods: Water quality testing and risk assessments of the drinking-water systems were conducted three weeks and 10 months post-Haiyan. Portable test kits were used to determine the presence of Escherichia coli and the level of residual chlorine in water samples. The level of risk was fed back to the water operators for their action.

Results: Of the 121 water samples collected three weeks post-Haiyan, 44\% were contaminated, while 65\% (244/373) of samples were found positive for $E$. coli 10 months post-Haiyan. For the three components of drinking-water systems - source, storage and distribution - the proportions of contaminated systems were $70 \%, 67 \%$ and $57 \%$, respectively, 10 months after Haiyan.

Discussion: Vulnerability to faecal contamination was attributed to weak water safety programmes in the drinking-water supply systems. Poor water quality can be prevented or reduced by developing and implementing a water safety plan for the systems. This, in turn, will help prevent waterborne disease outbreaks caused by contaminated water post-disaster.

A ccess to safe drinking-water is one of the most important public health concerns in an emergency setting. The greatest waterborne risk to health is the transmission of faecal pathogens. ${ }^{1}$ Escherichia coli, a thermotolerant bacterium, is widely used as an index of faecal contamination in drinking-water. ${ }^{2}$ This bacterium is abundant in human and animal faeces and is found in natural water and soil contaminated by faecal matters. Both the World Health Organization (WHO) guidelines and the Philippine National Standards for DrinkingWater use $E$. coli as the main indicator of microbiological contamination of drinking-water. ${ }^{1,3}$ Many important pathogens could be present if $E$. coli is detected, such as Vibro cholerae, Salmonella (typhi), pathogenic strains of E. coli, Giardia, Cryptosporidium and various viruses.

After Typhoon Haiyan, Region 8 experienced severe damage and destruction, ${ }^{4}$ including damage to water supply infrastructures.Three weeks after Haiyan, the Philippine Department of Health (DOH), together with WHO, organized two National Water Quality Monitoring Teams to undertake a rapid assessment of drinking-water quality in priority areas. After this, DOH and WHO organized training, provided portable test kits and developed a monitoring system to strengthen the capacity of local government units (LGUs) and to establish a system capable of managing and monitoring water quality at the LGU level - a situation that did not exist before Typhoon Haiyan.

This paper presents the findings from these two water quality surveys three weeks and 10 months after Typhoon Haiyan.

\section{METHODS}

Three weeks after Typhoon Haiyan, two National Water Quality Monitoring teams composed of water experts from DOH, Local Water Utilities Administration, Maynilad Water Services Incorporated, Manila Water Co. and WHO conducted rapid assessments in Region 8. Water testing was conducted over 11 days in November and December 2013 on two separate field trips in Leyte province and Eastern Samar provinces and Ormoc and Tacloban cities. The first field visit included Eastern Samar and some municipalities of Leyte and villages of Tacloban City. The second was for Ormoc City, additional municipalities in Leyte and villages of Tacloban City. 
Portable test kits were used to determine the presence of $E$. coli in water samples. The portable test kit used hydrolysable chromogenic substrates for the detection of enzymes of coliform bacteria employing the presence-absence, single $100 \mathrm{~mL}$ sample format based on Standard Methods for Water and Wastewater. ${ }^{5}$ Samples were collected from drinking-water sources, storage and distribution lines using DOH's prescribed standard procedures. Within the maximum holding time of six hours after collection, the water samples were placed in portable incubators for 18 hours maintained at $35^{\circ} \mathrm{C}$. E. coli presence was confirmed if fluorescence was observed in the discoloured water samples after exposure to ultraviolet lamps.

The level of residual chlorine was also measured using a digital colorimeter which provided results in less than five minutes. The Philippine National Standards for Drinking-water requires that residual chlorine be in a range of $0.30-1.5 \mathrm{ppm}$ to be effective in inactivating pathogens. ${ }^{3}$ This parameter indicates the level of protection of the water system from bacterial contamination. A hand-held Global Positioning System device recorded the geographic coordinates of the sampling points.

The same portable test kits were provided by WHO and DOH to LGUs eight months after Haiyan. These were used to train LGU teams on water testing, sanitary surveys, water treatment and water safety planning. ${ }^{4}$ During this training, the LGU water quality monitoring teams conducted testing of various types of drinkingwater systems (i.e. point sources, communal faucets and individual household piped connections).

Water testing was again conducted in the provinces of Leyte and Eastern Samar and the cities of Ormoc and Tacloban in September and December 2014, 10 months post-Haiyan by the recently trained LGU teams. The LGU teams prioritized sampling areas using these criteria: (1) a large population affected by Typhoon Haiyan; (2) those who remained most vulnerable to flooding; and (3) where drinking-water systems served large populations. The sampling points identified in the water testing by the LGU were not necessarily the same sampling points tested by the National Water Quality Monitoring Teams in November and December 2013. The level of residual chlorine was also tested.
Together with water quality testing, the LGU conducted risk assessments of the drinking-water systems using the sanitary inspection forms adopted from WHO (1997). ${ }^{6}$ The forms included a checklist of water supply system components from source to distribution, incorporating all potential points where hazards may be introduced. A risk score was given for every observed and perceived hazard in the system with the total risk score determining the level of risk of the water supply system. Remedial actions for the risks were provided in the form, and feedback was given to the operators of the water supply systems to address the risks.

The results of the water testing and risk assessment were recorded on the monitoring forms, entered into Excel spreadsheets and transmitted to $\mathrm{DOH}$ for consolidation and further analysis. Testing results were mapped using the Google Maps Engine software. We consolidated and analysed the data gathered by the LGU and presented these together with the findings of the rapid assessment.

\section{RESULTS}

The rapid assessment found nearly half of the water samples collected were positive for E. coli (53/121, $44 \%)$. Leyte province had the highest proportion of positive samples $(38 / 72,53 \%)$ and Ormoc City had the lowest $(1 / 16,6 \%)$ (Table 1$)$. The rapid assessment also found that three quarters of the water samples (90/121, $74 \%$ ) did not comply with the minimum residual chlorine level of $0.3 \mathrm{mg} / \mathrm{L}$. The province of Eastern Samar registered the highest proportion of non-complying residual chlorine level $(19 / 20,95 \%)$ and Ormoc City the lowest (10/16, 63\%) (Table 1).

Ten months after Haiyan, two thirds of the samples collected in Eastern Visayas were positive for E. coli (244/373, 65\%). Eastern Samar province had the highest proportion of contaminated samples $(134 / 170,79 \%)$ while Ormoc City remained the lowest $(22 / 62,36 \%)$ (Table 1$)$. The same survey revealed $93 \%$ of 311 water samples had residual chlorine below the minimum required level. Leyte and Eastern Samar provinces showed the highest proportions of water samples not complying with the minimum chlorine requirement at 98\% (89/91) and 95\% (161/170), respectively (Table 1 ). 
Table 1. Presence of $E$. coli and chlorine levels in drinking-water system components in Region 8, the Philippines, November-December 2013 and September-December 2014

\begin{tabular}{|c|c|c|c|c|c|c|c|c|c|}
\hline \multirow{3}{*}{$\begin{array}{c}\begin{array}{c}\text { Local } \\
\text { government } \\
\text { units }\end{array} \\
\text { Leyte }\end{array}$} & \multirow{3}{*}{$\begin{array}{l}\text { Component } \\
\text { Water source }\end{array}$} & \multicolumn{4}{|c|}{$\begin{array}{c}\text { Positive for E. coli } \\
n(\%)\end{array}$} & \multicolumn{4}{|c|}{$\begin{array}{c}\text { Non-compliant chlorine levels* } \\
n(\%)\end{array}$} \\
\hline & & \multicolumn{2}{|c|}{ Nov-Dec 2013} & \multicolumn{2}{|c|}{ Sept-Dec 2014} & \multicolumn{2}{|c|}{ Nov-Dec 2013} & \multicolumn{2}{|c|}{ Sept-Dec 2014} \\
\hline & & $15 / 21$ & (71) & $42 / 53$ & (79) & $20 / 21$ & (95) & $52 / 53$ & (98) \\
\hline & Storage & $5 / 8$ & $(62)$ & $2 / 3$ & (67) & $6 / 8$ & (75) & $3 / 3$ & (100) \\
\hline & Distribution & $18 / 43$ & $(42)$ & $21 / 35$ & (60) & $26 / 43$ & (60) & $34 / 35$ & $(97)$ \\
\hline Subtotal & & $38 / 72$ & (53) & $65 / 91$ & (71) & $52 / 72$ & (72) & $89 / 91$ & (98) \\
\hline \multirow[t]{3}{*}{ Eastern Samar } & Water source & $5 / 11$ & (45) & $75 / 87$ & (86) & $11 / 11$ & (100) & $87 / 87$ & (100) \\
\hline & Storage & \multicolumn{2}{|c|}{-} & $21 / 27$ & (78) & \multicolumn{2}{|c|}{-} & $25 / 27$ & (93) \\
\hline & Distribution & $4 / 9$ & (44) & $38 / 56$ & (68) & $8 / 9$ & (89) & $49 / 56$ & (87) \\
\hline Subtotal & & $9 / 20$ & (45) & $134 / 170$ & (79) & $19 / 20$ & (95) & $161 / 170$ & (95) \\
\hline \multirow[t]{3}{*}{ Tacloban City } & Water source & $5 / 7$ & (71) & $21 / 31$ & (68) & $7 / 7$ & (100) & $31 / 31$ & (100) \\
\hline & Storage & \multicolumn{2}{|c|}{-} & $0 / 2$ & (0) & \multicolumn{2}{|c|}{-} & $1 / 2$ & (50) \\
\hline & Distribution & $0 / 6$ & (0) & $2 / 17$ & (12) & $2 / 6$ & (33) & $6 / 17$ & (35) \\
\hline Subtotal & & $5 / 13$ & (38) & $23 / 50$ & (46) & 9/13 & (69) & $38 / 50$ & (76) \\
\hline \multirow[t]{3}{*}{ Ormoc City } & Water source & $0 / 5$ & (0) & $6 / 36$ & (17) & $5 / 5$ & (100) & \multicolumn{2}{|c|}{-} \\
\hline & Storage & $1 / 1$ & (100) & $8 / 14$ & (57) & $1 / 1$ & (100) & \multicolumn{2}{|c|}{-} \\
\hline & Distribution & $0 / 10$ & (0) & $8 / 12$ & (67) & $4 / 10$ & $(40)$ & \multicolumn{2}{|c|}{-} \\
\hline \multicolumn{2}{|l|}{ Subtotal } & $1 / 16$ & (6) & $22 / 62$ & (35) & $10 / 16$ & (63) & \multicolumn{2}{|c|}{ - } \\
\hline \multirow[t]{3}{*}{ Total } & Water source & $25 / 44$ & (57) & $144 / 207$ & (70) & $43 / 44$ & (98) & $170 / 171$ & (99) \\
\hline & Storage & $6 / 9$ & (67) & $31 / 46$ & (67) & $7 / 9$ & (78) & $29 / 32$ & (91) \\
\hline & Distribution & $22 / 68$ & (32) & $69 / 120$ & (57) & $40 / 68$ & (59) & $89 / 108$ & (82) \\
\hline Grand total & & $53 / 121$ & (44) & $244 / 373$ & (65) & 90/121 & (74) & $288 / 311$ & (93) \\
\hline
\end{tabular}

* $\quad$ Based on the Philippine National Standards for Drinking-water where residual chlorine should be in a range of $0.30-1.5 \mathrm{ppm} .^{3}$

"_", no samples taken.

The rapid assessment found faecal contamination, as indicated by the presence of $E$. coli, affected $57 \%$, $67 \%$ and $32 \%$ of source, storage and distribution components, respectively. Ten months after Haiyan E. coli presence was still high across all water supply system components $(70 \%$ source, $67 \%$ storage and $57 \%$ distribution) (Table 1 ).

The risk assessments identified the following risk factors: (1) damage to the water supply systems sustained in Typhoon Haiyan; (2) poor engineering design; (3) lack of protection against environmental hazards; (4) inadequate preventive maintenance; and (5) the presence of pollution from human activities (e.g. septic tanks, garbage disposal, open defecation) within a $25 \mathrm{~m}$ radius of water sampling points.

\section{DISCUSSION}

The overall water quality in both the rapid assessment conducted three weeks after Haiyan and the LGU monitoring 10 months after Haiyan was poor (44\% and $65 \%$, respectively). This was especially true for the specimens collected in Eastern Samar province almost a year after Haiyan, with more than three quarters faecally contaminated. Nearly half a million people living in the province of Eastern Samar would have been vulnerable to this contaminated water. Chlorination could have mitigated the risks to public health posed by faecal contamination in drinking-water, but as both surveys showed, non-compliance to the minimum required residual chlorine was very high: $74 \%$ in the rapid assessment three weeks after the typhoon and $93 \%$ for the LGU monitoring 10 months post-Haiyan. The poor water quality may be attributed to the damage Haiyan caused to sanitation facilities. The extensive destruction scattered human waste and infected wastewater which might have reached drinking-water sources. Lack of chlorination may be due to low budget allocation by the LGU or destruction of chlorinators by Haiyan.

Our results highlight that the problem with the water supply was widespread and long-term. More than half of all samples, collected from different components of the supply system, were contaminated, suggesting that faecal contamination was entering all parts of the system.

As historical water quality data was not available, we cannot assume that the unrepaired damage from Typhoon Haiyan was solely responsible for the poor water quality, but it was likely a significant contributing factor. Other 
risks that were identified included lack of engineering design to protect the system from environmental hazards, inadequate preventive maintenance and human interference too close to the water source. These risks may have existed before Haiyan, and they increased the contamination vulnerability of the weak system.

In other post-disaster studies, similar findings were noted. In 2011, following a flood in Thailand, a study evaluated the microbiological quality of tap water and found $92 \%$ of the samples had a total bacterial load that exceeded the Thai water quality standards. ${ }^{7}$ Another study found water samples in Banda Aceh two years after the tsunami were more contaminated when compared to reference points before the tsunami. ${ }^{8}$ Substandard drinking-water was found four weeks after a cyclone affecting a remote Pacific island. ${ }^{9}$ Three weeks after Haiyan, 105 cases of gastroenteritis were identified in Leyte, and the cause of the outbreak was associated with contaminated water. $^{10}$

Contaminated water is commonly the source of large outbreaks of diseases such as cholera, dysentery, typhoid fever and acute diarrhoea. ${ }^{1,11}$ This can be prevented by the application of a comprehensive risk assessment and risk management programmes implemented across all components of the systems from source to distribution.

Water safety plans are a risk management tool considered by WHO to be the most effective way of consistently ensuring the safety of drinking-water. Plans should include control measures for all identified risk factors. ${ }^{1}$ At the household level, the use of chemical or solar disinfection, filtration, boiling, sedimentation or a combination of these methods is recommended as an immediate intervention to deliver safe water postdisaster.

\section{CONCLUSION}

This study demonstrated that drinking-water supply systems were contaminated by pathogens as indicated by the presence of $E$. coli immediately and 10 months after Haiyan. Millions of people had potentially been consuming faecally contaminated water for almost a year following Typhoon Haiyan, increasing the risk of illness to an already vulnerable population. We recommend each LGU develop and implement a water safety plan to mitigate the risk of waterborne diseases both during non-emergency times and post-disaster. While LGU teams should continue their water quality monitoring and risk assessment activities as part of a water safety programme, action to rectify problems (such as fixing broken pipes or chlorination) should be undertaken to improve protection of water supply systems from contamination.

\section{Conflicts of interest}

None declared.

\section{Funding}

None.

\section{Acknowledgements}

We would like to thank the national water quality monitoring teams from DOH, Local Water Utilities Administration, WHO, Maynilad and Manila Water, as well as the provincial and city water quality monitoring teams for their support in the data gathering activities.

\section{References}

1. Guidelines for drinking-water quality, Fourth edition. Geneva, World Health Organization, 2011 (http://apps.who.int/iris/ bitstream/10665/44584/1/9789241548151_eng.pdf, accessed 12 August 2015).

2. Payment $P$, Waite M, Dufour A. Chapter 2: Introducing parameters for the assessment of drinking-water quality. In: World Health Organization and the Organization for Economic Co-operation and Development (editors). Assessing microbial safety of drinking-water: improving approaches and methods. London, IWA Publishing, 2003, pp. 47-78 (http://www.who. int/water_sanitation_health/dwq/9241546301full.pdf, accessed 12 August 2015).

3. Administrative Order No: 2007-0012: Philippine National Standards for Drinking-Water (9 March 2007). Manila, Department of Health, 2007 (http://www.Iwua. gov.ph/downloads_14/Philippine\%20 National\%20 Standards\%20for\%20Drinking\%20Water\%202007.pdf, accessed 12 August 2015).

4. McPherson M, Counahan M, Hall JL. Responding to Typhoon Haiyan in the Philippines. Western Pacific Surveillance and Response Journal, 2015, 6(Supp 1):1-4. doi:10.5365/ wpsar.2015.6.2.HYN_026

5. Method 9223: Chromogenic substrate coliform test (proposed). In: Franson MAH (editor). Standard methods for the examination of water and wastewater, 18th edition. Washington, DC, American Public Health Association, 1992: pp.63-64 (https://law.resource. org/pub/us/cfr/ibr/002/apha.method.9223.1992.pdf, accessed 12 August 2015).

6. Guidelines for drinking-water quality, 2nd edition - Volume 3: Surveillance and control of community supplies. Geneva, World Health Organization, 1997 (http://www.who.int/ water_sanitation_health/dwq/gdwq2v1/en/index2.html, accessed 12 August 2015). 
7. Chaturongkasumrit $Y$ et al. Microbiological evaluation of water during the 2011 flood crisis in Thailand. The Science of the Total Environment, 2013, 463:959-967. doi:10.1016/j. scitotenv.2013.06.071 pmid:23872186

8. Suhendrayatna M, Munawar E, Zaki M. Water quality assessment in the tsunami-affected areas of Banda Aceh. Jurnal Rekayasa Kimia dan Lingkungan, 2009, 7(1):1-4 (http://jurnal.unsyiah. ac.id/RKL/article/view/59/54, accessed 12 August 2015).

9. Mosley LM, Sharp DS, Singh S. Effects of a tropical cyclone on the drinking-water quality of a remote Pacific island. Disasters,
2004, 28:405-417. doi:10.1111/j.0361-3666.2004.00266.x pmid:15569381

10. Ventura RJ et al. A community-based gastroenteritis outbreak after Typhoon Haiyan, Leyte, Philippines, 2013. Western Pacific Surveillance and Response Journal, 2015, 6:1-6. doi:10.5365/ wpsar.2014.5.1.010 pmid:25960917

11. Wisner B, Adams J. Environmental health in emergencies and disasters: a practical guide. Geneva, World Health Organization, 2002 (http://www.who.int/water_sanitation_health/hygiene/ emergencies/em2002intro.pdf, accessed 12 August 2015). 